\title{
Absence of measles viral genomic sequence in intestinal tissues from Crohn's disease by nested polymerase chain reaction
}

First Department of Internal Medicine, Hirosaki University School of Medicine, Hirosaki, Japan.

Y Haga

O Funakoshi

K Kuroe

K Kanazawa

H Nakajima

H Saito

Y Murata

A Munakata

Y Yoshida

Correspondence to: Dr Y Haga, First

Department of Internal

Medicine, Hirosaki

Medicine, Hirosaki

Medicine, 5 Zaifucho, Hirosaki, 036 Japan.

Accepted for publication 24 July 1995

\begin{abstract}
The aetiology of Crohn's disease remains unknown, although evidence for a viral cause has long been sought. Recent studies have shown inflammation of the submucosal microvascular endothelium and granulomata, and endothelial cell cytoplasmic inclusions, consistent with paramyxovirus, were identified by electron microscopy suggesting a persistent measles virus infection in Crohn's disease. Measles, mumps, and rubella viruses were tested for Crohn's disease by polymerase chain reaction (PCR). RNA was extracted from resected intestinal specimens from 15 patients with Crohn's disease, 14 with ulcerative colitis, and 14 controls without inflammatory bowel disease. This was used to perform nested PCR after reverse transcription (RT) of the RNA to cDNA with primer pairs directed against two regions in the genome of the measles virus and one region in the mumps and rubella viral genomes. Despite enhanced sensitivity of nested RT-PCR, measles, mumps, and rubella viral genomic sequences were not found in any intestinal specimen.

(Gut 1996; 38: 211-215)
\end{abstract}

Keywords: Crohn's disease, measles virus, mumps virus, rubella virus, nested polymerase chain reaction, Southern hybridisation.

The cause of Crohn's disease remains undetermined, although many infectious agents have been implicated. ${ }^{1}$ The possibility that viruses play a part in Crohn's disease has long been sought. ${ }^{2}$ Gitnick et al reported the presence of viral agents isolated from ileal filtrates of patients with Crohn's disease that had been grown in continuous tissue culture of rabbit ileum. ${ }^{3}$ Electron microscopic studies showed clusters of viral particles which were consistent with a picornavirus. Whorwell et al found production of a cytopathic effect by intestinal filtrates of patients with Crohn's disease in cell monolayers. ${ }^{4}$ Electron microscopy indicated an RNA virus which belonged to reoviridae family. However, none of these reports have proved an aetiological relationship.

Wakefield et al, focusing on inflammation of the submucosal microvasculature, recently reported the identification by electron microscopy of endothelial cell cytoplasmic inclusions which were consistent with paramyxovirus. ${ }^{5-7}$
Both in situ hybridisation and immunohistochemical staining for nucleocapsid protein of measles virus were positive in cases of Crohn's disease, suggesting a persistent infection of measles virus. These data prompted us to investigate the relationship between measles virus and Crohn's disease. We tested for measles, mumps, and rubella viruses in Crohn's disease by polymerase chain reaction (PCR). We report the results of reverse transcription (RT) PCR using nested primers against measles, mumps, and rubella viral genomic sequences with RNA extracted from Crohn's disease, ulcerative colitis, and control intestinal tissues.

\section{Methods}

\section{PATIENTS}

Intestinal specimens from 15 patients with Crohn's disease, 14 with ulcerative colitis, and 14 controls without inflammatory bowel disease were obtained from First Department of Internal Medicine, Hirosaki University School of Medicine for RNA extraction. In each case, the diagnosis had been confirmed by clinical, radiological, and histological criteria. Table I shows each patient's age and sex, diagnosis, site of specimen, and time of storage. All specimens were resected materials and had been stored frozen at below $-70^{\circ} \mathrm{C}$ for between 1 month and 10 years. The postoperative time ranged from 20 minutes to 1.5 hours. Control specimens were resected tissues from patients with rectal or colonic cancer but no inflammatory disease; tissue blocks were taken from macroscopically normal bowel that was at least $5 \mathrm{~cm}$ from the tumour margin. All intestinal specimens of Crohn's disease and ulcerative colitis were selected from areas with macroscopically and histopathologically active disease.

CONTROL MEASLES, MUMPS, AND RUBELLA VIRUS RNA

RNA containing measles, mumps, and rubella viral genomes was extracted from concentrated supernatants of Vero E6 cell culture infected with the Toyoshima strain of measles virus, Enders or Miyahara strains of mumps virus, or M 33 strain of rubella virus respectively. RNA extracted from cell culture supernatant infected with the M 33 strain of rubella virus was used as a negative control for measles or mumps virus. RNA extracted from cell culture supernatant infected with the Toyoshima strain of 
TABLE I Materials

\begin{tabular}{|c|c|c|c|c|}
\hline $\begin{array}{l}\text { Specimen } \\
\text { No }\end{array}$ & $\begin{array}{l}\text { Age/sex of } \\
\text { patient }\end{array}$ & Diagnosis & $\begin{array}{l}\text { Site of } \\
\text { specimen }\end{array}$ & $\begin{array}{l}\text { Time in } \\
\text { storage }(y)\end{array}$ \\
\hline 1 & $27 / M$ & CD & Ileum & $0 \cdot 1$ \\
\hline 2 & $20 / M$ & CD & Ileum & $0 \cdot 2$ \\
\hline 3 & $26 / \mathrm{F}$ & CD & Ileum & $0 . \overline{8}$ \\
\hline 4 & $25 / M$ & CD & Ileum & 0.9 \\
\hline 5 & $28 / \mathrm{F}$ & CD & Ileum & 5 \\
\hline 6 & $24 / M$ & CD & Ileum & 7 \\
\hline 7 & $23 / M$ & CD & Colon & $0 \cdot 1$ \\
\hline 8 & $31 / F$ & CD & Colon & 0.3 \\
\hline 9 & $29 / \mathrm{F}$ & $\mathrm{CD}$ & Colon & 2 \\
\hline 10 & $19 / \mathrm{M}$ & CD & Colon & 5 \\
\hline 11 & $32 / \mathrm{M}$ & CD & Colon & 6 \\
\hline 12 & $24 / M$ & $C D$ & Colon & 8 \\
\hline 13 & $40 / F$ & $C D$ & Colon & 9 \\
\hline 14 & $30 / F$ & $\mathrm{CD}$ & Colon & 9 \\
\hline 15 & $25 / M$ & $\mathrm{CD}$ & Colon & 9 \\
\hline 16 & $55 / \mathrm{F}$ & UC & Colon & $0 \cdot 3$ \\
\hline 17 & $23 / \mathrm{F}$ & UC & Colon & 0.9 \\
\hline 18 & $29 / \mathrm{F}$ & UC & Colon & 4 \\
\hline 19 & $50 / \mathrm{F}$ & UC & Colon & 4 \\
\hline 20 & $43 / F$ & UC & Colon & 5 \\
\hline 21 & $18 / \mathrm{F}$ & UC & Colon & 7 \\
\hline 22 & $53 / F$ & UC & Colon & 7 \\
\hline 23 & $29 / \mathrm{F}$ & UC & Colon & 8 \\
\hline 24 & $38 / \mathrm{F}$ & UC & Colon & 8 \\
\hline 25 & $65 / F$ & UC & Colon & 9 \\
\hline 26 & $58 / \mathrm{F}$ & UC & Colon & 9 \\
\hline 27 & $64 / F$ & UC & Colon & 9 \\
\hline 28 & $42 / \mathrm{F}$ & UC & Colon & 9 \\
\hline 29 & $37 / F$ & UC & Colon & 9 \\
\hline 30 & $75 / F$ & CC & Colon & 1 \\
\hline 31 & $55 / \mathrm{F}$ & CC & Colon & 5 \\
\hline 32 & $70 / \mathrm{M}$ & RC & Colon & 7 \\
\hline 33 & $56 / F$ & CC & Colon & 7 \\
\hline 34 & $65 / M$ & $\mathrm{CC}$ & Colon & 7 \\
\hline 35 & $62 / \mathrm{M}$ & $\mathrm{CC}$ & Colon & 7 \\
\hline 36 & 55/M & CC & Colon & 7 \\
\hline 37 & $48 / \mathrm{F}$ & CC & Colon & 7 \\
\hline 38 & $67 / M$ & CC & Colon & 9 \\
\hline 39 & 61/M & RC & Colon & 9 \\
\hline 40 & 65/M & RC & Colon & 9 \\
\hline 41 & $58 / M$ & RC & Colon & 10 \\
\hline 42 & 54/M & CC & Colon & 10 \\
\hline 43 & $50 / \mathrm{F}$ & RC & Colon & 10 \\
\hline
\end{tabular}

$\mathrm{CD}=$ Crohn's disease; $\mathrm{UC}=$ ulcerative colitis; $\mathrm{RC}=$ rectal cancer; $\mathrm{CC}=$ colonic cancer.

measles virus was used as a negative control for rubella virus. The Enders strain of mumps virus was obtained from the American Type Culture Collection (Rockville, MD), and the other viruses were provided by $\mathrm{Dr}$ Yamada of National Institute of Health in Japan. Frozen brain tissue of a patient with subacute sclerosing panencephalitis (SSPE) was obtained from Department of Pathology, Brain Research Institute, Nigata University, Japan (kindly provided by Dr Ikuta). This SSPE case had a typical clinical course and neuropathological examination, and had positive immunohistochemical staining for measles virus and positive viral nucleocapsids by electron microscopy.

\section{RNA EXTRACTION}

RNA from frozen intestinal specimens and from infected cell culture supernatants was extracted using the acid guanidinium-phenol-chloroform method as described by Chomczynski et al. ${ }^{8}$ The tissue was minced on ice and homogenised at room temperature in $4 \mathrm{M}$ guanidinium thiocyanate; $25 \mathrm{mM}$ sodium citrate, $\mathrm{pH} 7 ; 0.5 \%$ sarcosyl; 0.1 M 2-mercaptoethanol solution with an equal volume of phenol; and $10 \%$ chloroform-isoamyl alcohol mixture (49:1) using physcotron (Microtec Nition, Chiba, Japan). Samples were centrifuged at $10000 \mathrm{~g}$ for 20 minutes at $4^{\circ} \mathrm{C}$. The aqueous phase was mixed with isopropanol to precipitate the RNA. The adequacy of extracted nucleic acid was assessed spectrophotometrically and by successful RT-PCR amplification of a portion of the normal human $\beta$-actin gene. ${ }^{9}$

PRIMERS AND PROBE

Oligonucleotide primer pairs for the measles, ${ }^{1011}$ mumps, ${ }^{12}$ and rubella, ${ }^{13}$ virus genes were selected as described by Godec et $a^{14}$ or by ourselves. The primer pair for the $\beta$-globin gene was obtained from Clontech Laboratories Inc (Palo Alto, CA). ${ }^{9}$ Primer pairs were designed to amplify segments of genomes in these viral genes between 400 and 650 base pairs long with one or more restriction enzyme cleavage sites. Nested primer pairs were selected internal to the first primer pairs. Table II shows the locations of the target segments within the viral genomes, the primer sequences, the size of the PCR products, and the predicted sizes of the fragments generated by restriction enzyme cleavage of the PCR products. The oligonucleotide probe was selected to detect the segment of genome for nucleocapsid protein of measles virus between the inner primer pair. The sequence of the oligonucleotide probe is as follows: 5'CGGCAGCTGATTCGGAGCTAAGAAGGTGGATAAAGTACAC3'.

\section{NESTED RT-PCR}

RNA was transcribed to CDNA with thermus thermophilus DNA polymerase using $5 \mu \mathrm{g}$ of template and the first round of amplification

TABLE II Oligonucleotide primer pairs used for nested reverse transcription polymerase chain reaction

\begin{tabular}{|c|c|c|c|c|c|c|}
\hline \multirow{2}{*}{$\begin{array}{l}\begin{array}{l}\text { Viral } \\
\text { genome }\end{array} \\
\text { Measles }\end{array}$} & \multirow{3}{*}{$\begin{array}{l}\begin{array}{l}\text { Gene region } \\
\text { amplified }\end{array} \\
\begin{array}{c}\text { Nucleocapsid } \\
\text { protein }\end{array}\end{array}$} & \multicolumn{2}{|c|}{ Primer sequences } & \multirow{2}{*}{$\begin{array}{l}\begin{array}{l}\text { Product size } \\
\text { (bp) }\end{array} \\
477\end{array}$} & \multicolumn{2}{|c|}{$\begin{array}{l}\text { Restriction enzyme and } \\
\text { fragment sizes (bp) }\end{array}$} \\
\hline & & Outer & $\begin{array}{l}\text { 5'GGTTCGGATGGTTCGAGAACA3' } \\
\text { 5'GGTTCATCAAGGACTCAAGTG3' }\end{array}$ & & Alu I & $138 / 11 / 328$ \\
\hline & & Inner & $\begin{array}{l}\text { 5'TGAAGTGCAAGACCCTGAGGG3' } \\
\text { 5'TTCATGCAGTCCAAGAGCAGG3' }\end{array}$ & 400 & $A l u \mathrm{I}$ & $101 / 11 / 288$ \\
\hline & Fusion protein & Outer & $\begin{array}{l}\text { 5'GGCAATTGAGGCAATCAGACA3' } \\
\text { 5'CTTGAGAGCCTATGTTGTACG3' }\end{array}$ & 452 & Ava II & $190 / 262$ \\
\hline & & Inner & $\begin{array}{l}\text { 5'GATGATATTGGCTGTTCAGGG3' } \\
\text { 5'CTTAATCTCGGACAGCGTCGG3' }\end{array}$ & 367 & Ava II & $143 / 224$ \\
\hline \multirow[t]{2}{*}{ Mumps } & \multirow{2}{*}{$\begin{array}{l}\text { Haemagglutinin } \\
\text { neuraminidase } \\
\text { glycoprotein }\end{array}$} & Outer & $\begin{array}{l}\text { 5'CACCCAATGGTTGCACAAGAA3' } \\
\text { 5'CCAGGCACAGACAAGAAATGC 3' }\end{array}$ & 632 & Alu I & $208 / 424$ \\
\hline & & Inner & $\begin{array}{l}\text { 5'TCTCTAGGTAAGACACACTGG3' } \\
\text { 5'GAAGTATGATCTCAAAGCACG3' }\end{array}$ & 546 & Alu I & $176 / 370$ \\
\hline \multirow[t]{2}{*}{ Rubella } & \multirow[t]{2}{*}{ E1 protein } & Outer & $\begin{array}{l}\text { 5'TCAACGCCTACTCCTCTGG3' } \\
\text { 5'GGGCTCCCGAGGCCCCACCGGG3' }\end{array}$ & 409 & Nae I & $257 / 142$ \\
\hline & & Inner & $\begin{array}{l}\text { 5'GGCCTCTTACTTCAACCCTGG3' } \\
\text { 5'CCGAGGCCCCACCGGGACTG3' }\end{array}$ & 369 & Nae I & $223 / 146$ \\
\hline
\end{tabular}




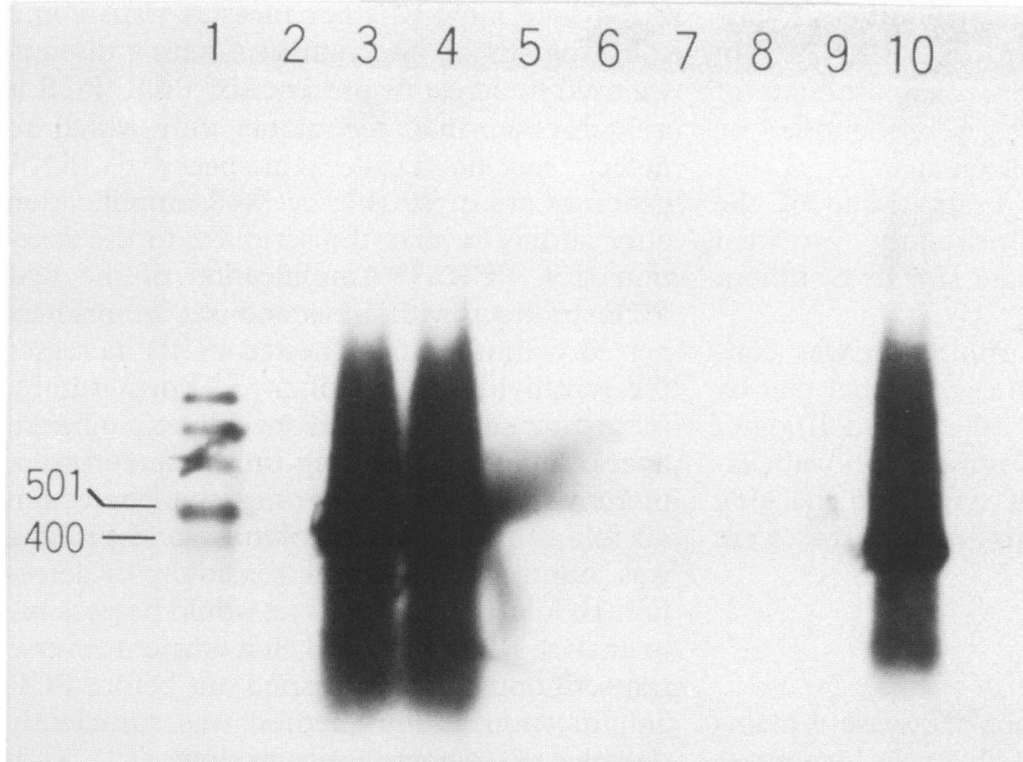

Figure 1: Southern blot of control measles virus (lanes 3-8) and subacute sclerosing panencephalitis tissue (lane 10) derived DNA amplified with a primer pair for the nucleocapsid protein of measles virus. Lane 1 - molecular weight marker VIII, digoxigenin labelled (Boehringer Mannheim Biochemica); lanes 2 and 9 -blank; lane 3 -polymerase chain reaction (PCR) products from $100 \mathrm{fg}$ of $R N A$ from measles infected cell culture diluted in intestinal $R N A$ extract from control tissue; lanes 3-8-PCR products from serial 10 fold dilutions of RNA; lane 10-PCR products in tissue from patients with subacute sclerosing panencephalitis.

was conducted as described by Myers et al ${ }^{15}$ except that $20 \mathrm{pmol}$ of each outer downstream and upstream primers were added before the RT assay and the cycles were increased to 50 (Perkin-Elmer Cetus DNA Thermal Cycler, PJ2000).

After completion of the first round of amplification, a second round of amplification was undertaken using a PCR reaction mixture containing $10 \mathrm{mM}$ Tris- $\mathrm{HCl}(\mathrm{pH} 8.3), 50 \mathrm{mM}$ $\mathrm{KCl}, 1.5 \mathrm{mM} \mathrm{MgCl}_{2}$, and $0.001 \%$ gelatin. The concentration of each nested primer was 1.0 $\mu M$ and in the final step, after adding 5 units of Taq DNA polymerase (Amplitaq, Cetus), $10 \mu \mathrm{l}$ of the first PCR reaction mixture was added to the tube, which was then briefly centrifuged. The thermal cycle profile was identical to the first round of amplification except that the initial $\mathrm{RT}$ step at $70^{\circ} \mathrm{C}$ for 15 minutes was omitted.

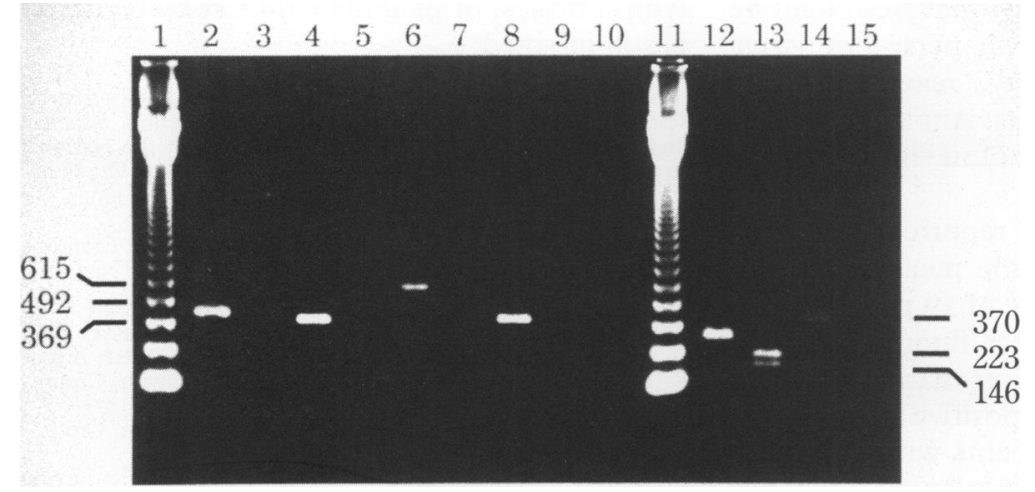

Figure 2: Agarose gel of polymerase chain reaction (PCR) products from measles infected (lanes 2 and 4), mumps infected (lane 6), rubella infected (lane 8), and negative control lanes 3, 5, 7, and 9) cell cultures. Lanes 1 and $11-123$ bp DNA ladder (Gibco-BRL); lanes 2 and 3 - nucleocapsid protein products of measles virus; lanes 4 and 5 - fusion protein products of measles virus; lanes 6 and 7 - haemagglutinin neuraminidase protein products of measles virus; lanes 6 and $7-$ haemagglutinin neuraminidase
glycoprotein products of mumps virus; lanes 8 and $9-E 1$ protein products of rubella virus; lane 10 - blank, lanes 12-15 respectively - Alu I, Ava II, Alu I, and Nae I digests of products in lanes $2,4,6$, and 8 . Note that some smaller restriction fragments are not well visualised.
Each tissue sample was run in triplicate with one buffer only as a negative control, and each experiment included one positive control. Stringent precautions were taken to avoid contamination throughout tissue processing, RNA extraction, and PCR steps. ${ }^{16}$

\section{GEL ELECTROPHORESIS AND SOUTHERN} HYBRIDISATION

Ten $\mu l$ of each first and second round PCR products were evaluated on $1.5 \%$ agarose gel electrophoresis via ethidium bromide staining. Identity of the PCR products was confirmed by subsequent cleavage with restriction enzymes at predetermined sites to yield a predicted fragment. All PCR products for nucleocapsid protein of measles virus were subjected to Southern hybridisation to digoxigenin-tailed oligonucleotide probe and to autoradiography, as previously described. ${ }^{17}$

\section{Results}

Nested RT-PCR was performed with RNA from 43 intestinal specimens using primer pairs directed against two regions in the measles viral genome and one region of the mumps and rubella viral genomes. A specific PCR product was detected with each primer pair after the first round of amplification using a control RNA template, and a second round of amplification with a nested primer pair substantially increased the sensitivity. When $1.0 \mu \mathrm{g}$ of RNA from concentrated supernatants of Vero cell culture infected with measles virus was serially diluted 10 fold in RNA extract containing $5 \mu \mathrm{g}$ of RNA from intestinal control tissue, PCR products generated with the primers for nucleocapsid protein gene of the measles virus were visualised at a dilution of 1:10 after the first round of amplification and $1: 10^{7}$ dilution after the second round of amplification with nested primers. Blotting and probing increased the sensitivity of detection 10 fold (Fig 1). The minimum detectable level for nucleocapsid protein gene was equivalent to almost 1 PFU of measles virus. Spiking the homogenate from $250 \mathrm{mg}$ of control intestinal tissue with $5 \mathrm{pg}$ of RNA from a measles infected cell culture ensured that products of the appropriate size were amplified and the detectable level for nucleocapsid gene corresponded to $100 \mathrm{fg}$ of RNA from measles infected cell culture in the material added to the PCR mixture. PCR products generated with the primers for the fusion protein gene of the measles virus were visualised at a dilution of $1: 10^{2}$ and $1: 10^{7}$ after the first and second rounds of amplification respectively. PCR products generated with the primers for haemagglutinin neuraminidase glycoprotein of mumps virus were visualised at a dilution of $1: 10$ and $1: 10^{7}$ after first and second rounds of amplification respectively. PCR products generated with the primers for the $\mathrm{E} 1$ protein gene of rubella virus were visualised at a dilution of $1: 10^{3}$ and $1: 10^{5}$ after first and second round of amplification respectively.

No specific PCR product from viruses was detectable in any specimens with any primer 
pairs on either agarose gel or Southern hybridisation, although positive control RNA from each virus consistently provided products of the appropriate size, which were identified by restriction enzyme analysis on agarose gel (Fig 2) and RNA from the brain tissue of the patient with SSPE consistently provided products of the appropriate size by Southern hybridisation (Fig 1).

The absence of PCR inhibition was confirmed in all samples with each primer pair by spiking each with $100 \mathrm{fg}, 100 \mathrm{fg}$, and $10 \mathrm{pg}$ of RNA from measles-, mumps-, and rubellainfected cell cultures respectively and checking that products of the appropriate size were detected.

\section{Discussion}

The pathogenesis of Crohn's disease remains unknown, although a possible role for viruses has long been sought. Wakefield et al, in a recent report of inflammation of the intestinal submucosal microvascular endothelium and granulomata, suggested that vasculitis is an early event in Crohn's disease. ${ }^{56}$ In 1993, they reported that electron microscopy detected paramyxovirus-like inclusions in foci of the microvascular inflammation of Crohn's disease and suggested that the measles virus is capable of causing persistent infection in the intestine of patients with Crohn's disease. ${ }^{7}$ Those particles were identified in all nine Crohn's disease patients, whereas no evidence of particles was found in either two patients with ulcerative colitis or in two controls with no inflammatory bowel disease. Immunohistochemical staining for the nucleocapsid protein of measles virus was positive in 13 of the 15 patients with Crohn's disease, localised to foci of granulomatous inflammation, but was not seen in either cases of intestinal tuberculosis or negative controls. In addition, positive in situ hybridisation for negative strand RNA encoding the nucleocapsid protein of measles virus was obtained in all 10 cases of Crohn's disease, four of 10 cases of ulcerative colitis, and three of 10 controls. With regard to the positive in situ hybridisation in ulcerative colitis and controls, they discussed the possibility that this might be related to the strain of the persistent virus, inherent host susceptibility, reactivity, or a combination of these factors. Another possibility might be the specificity of in situ hybridisation for measles virus.

In 1983 Miyamoto et al reported the detection of matrix protein of the measles virus in the cells of tissues from five of 19 patients with Crohn's disease by indirect fluorescent antibody method using anti-matrix protein monoclonal antibody. No positive staining was obtained in any of the patients with ulcerative colitis, intestinal tuberculosis, or controls without inflammatory bowel disease. ${ }^{18} \mathrm{~A}$ subsequent immunoblotting study failed to detect any antigen in the tissue extraction from patients with Crohn's disease. ${ }^{19} 20$ There might be a possibility of detecting the epitope of the associated antigen of another substance by immunohistochemical method.
To determine whether measles virus could cause persistent infection in Crohn's disease, we tried to detect its presence by PCR. PCR is a highly sensitive technique with which to detect specific DNA sequences. ${ }^{21} 22$ RNA genomes are detectable by PCR amplification after adding reverse transcriptase to the reaction (RT PCR). ${ }^{23}$ Amplification of the first PCR product with a second set of primers nested within the first (nested PCR) increases the sensitivity and specificity. ${ }^{24}$ Furthermore, for greater sensitivity and specificity, Southern hybridisation and blotting can be undertaken, thereby increasing the sensitivity of detection 10 fold. ${ }^{25}$ In our study, blotting and probing was found to increase the sensitivity of detection 10 fold. Theoretically, it would be possible to analyse RNA in single cell if efficient reverse transcription could be carried out before PCR amplification. ${ }^{26}$ Our method was sufficiently sensitive to detect levels as low as 1 viral genomic RNA in an assay for the nucleocapsid protein gene of measles virus.

Mumps and rubella viruses were selected for this study in addition to measles, because they are RNA viruses and specific for primates, and both measles and rubella viruses can persist in the central nervous system as latent infections for years. ${ }^{27}$ The specimens from patients with Crohn's disease were taken from areas of macroscopically and histopathologically confirmed active disease. In this study, the primer pairs for the nucleocapsid protein of the measles virus were selected in the segment of the genome which is identical to the probe used for in situ hybridisation by Wakefield et al. ${ }^{10}$ Despite the high sensitivity of nested RT-PCR, no measles, mumps, or rubella viral RNA was detected in intestinal tissue from subjects with Crohn's disease, ulcerative colitis, or controls.

Failure of nested RT-PCR to detect measles, mumps, or rubella viral genomes in the intestinal tissues of Crohn's disease, ulcerative colitis, or controls argues against a persistent measles infection in patients with Crohn's disease. Despite these negative results, a continued search for viruses in various areas of the intestine, including the lymph nodes, of patients with Crohn's disease is still justified.

This work was supported by a grant (no 05404029) for general scientific research from The Ministry of Education, Science, and Culture of Japan. We thank Dr Yamada of the National Institute of Health in Japan for providing viruses and Drs Ikuta, Takahashi, and Yamada of Nigata University in Japan for providing the tissue of SSPE.

Part of this work was presented to the 10th World Congress of Gastroenterology, October 1994.

1 Chiodini RJ, van Kruningen HJ, Merkal RS, Thayer WR, Coutu JA. Characteristics of an unclassified mycobacterium species isolated from patients with Crohn's disease. F Clin Microbiol 1984; 20: 966-71.

2 Mitchell DN, Rees RJW. Agent transmissible from Crohn's disease tissue. Lancet 1970; ii: 168-71.

3 Gitnick GL, Rosen VJ. Electron microscopic studies of vira agents in Crohn's disease. Lancet 1976; ii: 217-9.

4 Whorwell PJ, Phillips CA, Beeken WL, Little PK, Roessner $\mathrm{KD}$. Isolation of retrovirus-like agents from patients with Crohn's disease. Lancet 1977; i: 1169-71.

5 Wakefield AJ, Sawyerr AM, Dhillon AP, Pittilo RM, Rowles PM, Lewis AAM, et al. Pathogenesis of Crohn's disease: Multifocal gastrointestinal infarction. Lancet 1989; ii: 1057-62.

6 Wakefield AJ, Sankey EA, Dhillon AP, Sawyerr AM, More $\mathrm{L}$, Sim R, et al. Granulomatous vasculitis in Crohn's disease. Gastroenterology 1991; 100: 1279-87. 
7 Wakefield AJ, Pittilo RM, Sim R, Cosby SL, Stephenson $\mathrm{JR}$, Dhillon AP, et al. Evidence of persistent measles virus infection in Crohn's disease. $\mathcal{F}$ Med Virol 1993; 39: 345-53.

8 Chomczynski P, Sacchi N. Single-step method of RNA isolation by acid guanidinium thiocyanate-phenol-chloroisolation by acid guanidinium thiocyanate-phenol-ch

9 Nakajima-Iijima S, Hamada H, Reddy P, Kakunaga T. Molecular structure of the human cytoplasmic $\beta$-actin gene: Interspecies homology of sequences in the introns. Proc Natl Acad Sci USA 1985; 82: 6133-7.

10 Rosenblatt S, Eizenberg O, Ben-Levy R, Lavie V, Bellini WJ. Sequence homology within the morbilliviruses. $\mathcal{F}$ Virol 1985; 53: 684-90.

11 Buckland R, Gerald C, Barker R, Wild TF. Fusion glycoprotein of measles virus: Nucleotide sequence of the gene and comparison with other paramyxoviruses. 7 Gen Virol 1987; 68: 1695-703.

12 Waxham MN, Aronowski J, Server AC, Wolinsky JS, Smith JA, Goodman HM. Sequence determination of the JA, Goodman HM. Sequence determination of

13 Nakhasi HL, Meyer BC, Liu T-Y. Rubella virus CDNA Sequence and expression of E1 envelope protein. $\mathcal{F}$ Biol Chem 1986; 261: 16616-21.

14 Godec MS, Asher DM, Murray RS, Shin ML, Greenham LW, Gibbs Jr CJ, et al. Absence of measles, mumps, and rubella viral genomic sequences from multiple sclerosis brain tissue by polymerase chain reaction. Ann Neurol 1992; 32: 401-4.

15 Myers TW, Gelfand DH. Reverse transcription and DNA amplification by a thermus thermophilus DNA polymerase. Biochem 1991; 30: 7661-6.

16 Kwok S, Higuchi R. Avoiding false positives with PCR. Nature 1989; 339: 237-8.

17 During K. Ultrasensitive chemiluminescent and colorigenic detection of DNA, RNA, and proteins in plant molecular biology. Anal Biochem 1991; 196: 433-8.

18 Miyamoto $\mathrm{H}$, Tanaka $\mathrm{T}$, Tanimoto $\mathrm{H}$, Miyamoto $\mathrm{H}$, Minami $\mathrm{K}$, Isimizu $\mathrm{H}$, et al. Studies for viral antigen in intestinal tissues from patients with Crohn's disease and ulcerative colitis (in Japanese). Annual Report of the Research Committee of IBD. Nara: The Ministry of Health and Welfare of Japan, 1983: 48-50.

19 Miyamoto $H$, Tanaka $T$, Kitamoto $T$, Tanimoto $H$, Miyamoto H, Hiroi K, et al. Studies for viral antigen in intestinal tissues from patients with Crohn's disease and intestinal tissues from patients with Crohn's disease and ulcerative colitis (in Japanese). Annual Report of the
Research Committee of IBD. Nara: The Ministry of Health and Welfare of Japan, 1984: 50-3.

20 Miyamoto $\mathrm{H}$, Shimoyama T, Utsunomiya J, Yagita A Studies for causal agent on Crohn's disease. Participation in measles virus related materials - (in Japanese). Annual Report of the Research Committee of IBD. Tokyo: The Ministry of Health and Welfare of Japan, 1993: 122-5.

21 Saiki RK, Scharf S, Faloona F, Mullis KB, Horn GT, Erlich $\mathrm{HA}$, et al. Enzymatic amplification of $\beta$-globin genomic sequences and restriction site analysis for diagnosis of sickle cell anemia. Science 1985; 230: 1350-4.

22 Saiki RK, Gelfand DH, Stoffel S, Scharf SJ, Higuchi R

Horn GT, et al. Primer-directed enzymatic amplification of DNA with a thermostable DNA polymerase. Science 1988; 239: 487-91.

23 Veres G, Gibbs RA, Scherer SE, Caskey CT. The molecuar basis of the sparse fur mouse mutation. Science 1987 237: $415-7$.

24 Mullis KB, Faloona FA. Specific synthesis of DNA in vitro via a polymerase-catalyzed chain reaction. Methods Enzymol 1987; 155: 335-50.

25 Fidler HM, Rook GM, Johnson NM, McFadden J. Mycobacterium tuberculosis DNA in tissue affected by Mycobacterium tuberculosis DNA

$26 \mathrm{Li} \mathrm{H}$, Gyllensten UB, Cui X, Saiki RK, Erlich HA Arnheim N. Amplification and analysis of DNA Arnheim N. Amplification and analysis of DNA sequences in single

27 Ahmed R, Stevens JG. Viral persistence. In: Fields BN, Knipe DM, Chanock RM, Hirsch MS, Melnick JL Monath TP, et al, eds. Virology. 2nd ed. New York: Raven Press, 1990: 241-66. 